\title{
СИСТЕМНЫЙ СПЕКТРАЛЬНЫЙ АНАЛИЗ ИНФРАЗВУКОВОГО СИГНАЛА, СГЕНЕРИРОВАННОГО ЧЕЛЯБИНСКИМ МЕТЕОРОИДОМ
}

\author{
О. В. ЛАЗОРЕНКО, Л. Ф. ЧЕРНОГОР \\ Харьковский национальный университет, \\ Украина, Харьков, 61077, пл. Свободы, 4
}

\begin{abstract}
Аннотация. Приведены результаты системного спектрального анализа, использующего ряд линейных и нелинейных интегральных преобразований, временных регистраций акустического сигнала, сгенерированного Челябинским метеороидом и зарегистрированного инфразвуковой станцией в Антарктиде. Проанализирована тонкая время-частотная структура сигнала.
\end{abstract}

Ключевые слова: спектральный анализ; линейное интегральное преобразование; нелинейное интегральное преобразование; показатель широкополосности; структура сигнала; параметры источника; канал распространения; задача обнаружения и идентификации

\section{1. ВВЕДЕНИЕ}

Инфразвуковые волны, возникшие после пролета и взрыва Челябинского тела, зарегистрированы инфразвуковыми станциями международной системы мониторинга ядерных испытаний с энерговыделением не менее 1 кт, а также станциями, расположенными в ряде геофизических обсерваторий. Ближайшая от места взрыва метеороида станция расположена в г. Актюбинск, Республика Казахстан (расстояние от источника инфразвука $R \approx 540$ км), наиболее удаленная станция - в Антарктиде, для которой $R$ составляет 15500 км (прямой сигнал) и 25000 км (обратный сигнал).

Порожденные Челябинским метеороидом инфразвуковые волны, испытав многократные отражения, преломление и рассеяние в атмосфере и преодолев расстояние в тысячи километров зарегистрированы чувствительными микробарографами. Амплитуда и спектр инфразвука несут в себе информацию об источнике волн и параметрах атмосферы [1-9].
Результаты наблюдений инфразвукового эффекта Челябинского метеороида представлены в [10-13], а результаты теоретических оценок — в [14-17].

Для повышения точности определения параметров (энергия, мощность, время и характер воздействия, время-частотное распределение энергии, распределение энергии по вызываемым физическим процессам, и т.п.) источников инфразвука, таких как землетрясения, взрывы вулканов, падения крупных космических тел естественного и техногенного происхождения, стартов и полетов ракет и самолетов, мощных взрывов, а также их селекции требуется знание тонкой время-частотной структуры инфразвуковых сигналов. Поскольку подобные сигналы, будучи реакцией открытой нелинейной динамической системы Земля-атмосфера-ионосфера-магнитосфера (ЗАИМ) на действие мощного нестационарного источника энерговыделения являются, как правило, кратковременными, сверхширокополосными 


\section{БИБЛИОГРАФИЧЕСКИЙ СПИСОК}

1. Reed, J. W. Airblast overpressure decay at long ranges. J. Geophys. Res., Vol. 77, P. 1623-1629, 1972. DOI: http://doi.org/10.1029/JC077i009p01623.

2. ReVelle, D. O. On meteor-generated infrasound. $J$. Geophys. Res., Vol. 81, P. 1217-1230, 1976. DOI: 10.10 29/JA081i007p01217.

3. Edwards, W. N.; Brown, P. G.; ReVelle, D. O. Estimates of meteoroid kinetic energies from observations of infrasonic airwaves. J. Atmos. Solar-Terr. Phys., Vol. 68, No. 10, P. 1136-1160, 2006. DOI: 10.1016/j.jastp. 2006.02.010.

4. Stevens, J. L.; Adams, D. A.; Baker, G. E.; Murphy, J. R. Infrasound scaling and attenuation relations from Soviet explosion data and instrument design criteria from experiments and simulations. Proc. of 21th Annual Seismic Research Symposium on Monitoring a CTBT, 1999, pp. 185-194.

5. Silber, E. A.; ReVelle, D. O.; Brown, P. G.; Edwards, W. N. An estimate of the terrestrial influx of large meteoroids from infrasonic measurements. $J$. Geophys. Res., Vol. 114, P. 1-8, 2009. DOI: 10.1029/ 2009JE003334.

6. Edwards, W. N. Meteorgenerated Infrasound: Theory and Observation. Dordrecht, Netherlands: Springer, 2010, pp. 361-414.

7. Silber, E. A.; Le Pichon, A.; Brown, P. G. Infrasound detection of a near-Earth object impact over Indonesia on 8 October 2009. Geophys. Res. Lett., Vol. 38, No. 12, 2011. DOI: 10.1029/2011GL047633.

8. Ens, T. A.; Brown, P. G.; Edwards, W. N.; Silber, E. A. Infrasound production by bolides: A global statistic- al study. J. Atmos. Solar-Terr. Phys., Vol. 80, P. 208-229, 2012. DOI: 10.1016/j.jastp.2012.01.018.

9. Емельяненко, В.В.; Попова, О. П.; Чугай, Н.Н.; Шеляков, М. А.; Пахомов, Ю. В.; Шустов, Б. М.; Шувалов, В.В.; Бирюков, Е.Е.; Рыбнов, Ю.С.; Мааров, М.Я.; Рыхлова, Л.В.; Нароенков, С.А.; Карташова, А.П.; Харламов, В. А.; Трубецкая, И. А. Астрономические и физические эффекты Челябинского события 15 февраля 2013 г. Астрономический вестник, Т. 47, № 4, C. $262-277,2013$. DOI: 10.7868/S0320930X13040130.

10. Рыбнов, Ю. С.; Попова, О.П.; Харламов, В.А.; и др. Оценка энергии Челябинского болида по инфразвуковым измерениям. Динамические проиессы в геосферах. Сб. науч. тр. ИДГ РАН. М.: Геос, 2013. Вып. 4, C. 21-31.

11. Алпатов, В.В.; Буров, В.А.; Вагин, Ю.П.; и др. Геофизические условия при взрыве Челябинского (Чебаркульского) метеороида 15.02.2013 г. М.: ФГБУ ИПГ, 2013. $37 \mathrm{c.}$

12. Сорокин, А.Г. Об инфразвуковом излучении Челябинского метеороида. Труды XXIV Всероссийской научной конференции. Распространение радиоволн. PРВ-24, Иркутск, 29 июня - 5 июля 2014. 2014, Т. III, C. 242-245.

13. Le Pichon, A.; Ceranna, L.; Pilger, C.; Mialle, Pierrick; Brown, David; Herry, Pascal; Brachet, Nicolas. The 2013 Russian fireball largest ever detected by CTBTO infrasound sensors. Geophys. Res. Lett., Vol. 40, No. 14, P. 3732-3737, 2013. DOI: 10.1002/grl.50619.

14. Черногор, Л.Ф.Плазменные, электромагнитные и акустические эффекты метеорита «Челябинск». Инженерная физика, № 8, C. 23-40, 2013. URL: https://elibrary.ru/item.asp?id=21790207.

15. Черногор, Л.Ф.; Розуменко, В. Т. Физические эффекты пролета Челябинского метеорита. ВАНT, Т. 86, № 4, C. 136-139, 2013.

16. Черногор, Л.Ф.Основные эффекты падения метеорита Челябинск: результаты физико-математического моделирования. Материаль Всероссийской научной конферениии «Метеорит Челябинск - год на Земле». Челябинск, 2014, С. 229-264.

17. Черногор, Л.Ф. Физические эффекты пролета Челябинского метеорита. Доповіді НАН України, № 10, C. 97-104, 2013. URL: http://dspace.nbuv.gov.ua/ handle/123456789/86192.

18. Лазоренко, О.В.; Черногор, Л. Ф. Сверхиирокополосные сигналь и прочессы. Харьков: ХНУ им. В.Н.Каразина, 2009. 576 с.

19. Лазоренко, О.В.; Черногор, Л.Ф.Системный спектральный анализ сигналов: теоретические основы и практические применения. Радиофизика и радиоастрономия, Т. 12, № 2, C. 162-182, 2007. URL: http:// rpra-journal.org.ua/index.php/ra/article/view/600.

20. Deutsche IMS-Stationen, http://www.bgr.bund. $\mathrm{de} /$ EN/Themen/Seismologie/Kernwaffenteststopp_en/\% C3\%9Cberwachungsnetz en/Deutsche-IMS-Stationen/de utsche-ims-stationen inhalt.html. 
21. Cansi, Y. An automated seismic event processing for detection and location: The P.M.C.C. method. Geophys. Res. Lett., Vol. 22, No. 9, P. 1021-1024, 1995. DOI: $10.1029 / 95 \mathrm{GL} 00468$.

22. Лазоренко, О.В.Использование атомарных функций в Чои-Вильямс-анализе сверхширокополосных сигналов. Известия вузов. Радиоэлектроника, Т. 52，№ 8， C. 3-12，2009. URL: http://radio.kpi.ua/ article/view/S0021347009080019.

23. Пасечник, И.П.Наука доказала: ядерные взрывы можно обнаружить, где бы они ни производились. Природа, № 7, С. 3-12, 1962.

24. Голицын, Г.С.; Докучаев, В.П.Излучение акустико-гравитационных волн при движении метео- ров в атмосфере. Изв. АН СССР. Физика атмосферы и океана, Т. 13, № 9, С. 926-936, 1977.

25. Госсард, Э.; Хук, У. Волны в атмосфере. Пер. с англ. И. М.Шейнис под ред. Г. С. Голицын. М.: Мир, 1978. $532 \mathrm{c}$.

26. Черногор, Л.Ф.Колебания геомагнитного поля, вызванные пролетом Витимского болида 24 сентября 2002 г. Геомагнетизм и аэрономия, Т. 51, № 1, С. 119-132, 2011.

27. Черногор, Л.Ф. Физика и экология катастроф. Х.: ХНУ им. В.Н.Каразина, 2012. 556 с. 